\section{The Golden-bellied Mangabey Cercocebus Chrysogaster (PRIMATES: CERCOPITHECIDAE): DISTRIBUTION AND CONSERVATION STATUS}

\section{Bila-Isia Inogwabini ${ }^{1} \&$ Jo A. Myers Thompson ${ }^{2}$}

${ }^{1}$ Durrell Institute for Conservation and Ecology, University of Kent at Canterbury, UK

${ }^{1}$ Current address: Swedish University of Agricultural Sciences, Valsätra-Ultuna, Sweden

${ }^{2}$ Lukuru Wildlife Research Project, Democratic Republic of Congo

${ }^{1}$ bi4@kentforlife.net (corresponding author), ${ }^{2}$ jat434@aol.com

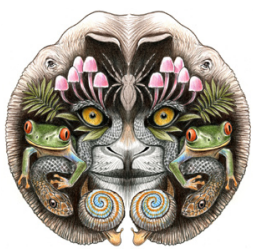

ISSN

Online 0974-7907

Print 0974-7893

\begin{abstract}
During the period 1994 through 2007, three intermittent and discontinuous surveys were conducted which documented the presence or absence of Cercocebus chrysogaster (Golden-bellied Mangabey). The three surveys were performed within the forest block areas of: (1) the region including the southern sector of the Salonga National Park (SNP) to the Sankuru River, (2) the region between Lokoro and Salonga-Looto Rivers inside the SNP, and (3) the region between the Kwa-Kasai and the Lulonga Rivers, west of Lake Maindombe. The results indicated that $C$. chrysogaster currently inhabits a very restricted range of approximately $70,000 \mathrm{~km}^{2}$; the species is now absent in more than $37 \%\left(25,000 \mathrm{~km}^{2}\right)$ of its presumed historical range. Classification of the habitat using satellite images indicated that the species occupied a region where $58.15 \%$ was swamp forest. Patterns of the species distribution and its conservation status lead to the conclusion that the species is highly threatened. The principal threats are the result of human pressure, particularly hunting for bushmeat and pet commerce. Logging constitutes a further potential threat because almost the entire range of the species is within logging concessions.
\end{abstract}

Keywords: Bushmeat, distribution, Golden-bellied Mangabey, pet trade.

French Abstract: Pendant la période allant de 1994 à 2007, trois recensements intermittents et discontinus furent organisés et avaient documenté la présence ou l'absence de Cercocebus chrysogaster (singe à ventre doré). Les trois recensements ont été organisés dans les blocs forestiers de: (1) la région incluant le secteur sud du Park National de la Salonga (PNS) jusqu'à la Rivière Sankuru, (2) la région entre les rivières Lokoro et Salonga-Looto à l'intérieur de PNS et (3) la région entre les rivières Kwa-Kasai et Lulonga à l'Ouest de Maindombe. Les résultats de ces recensements indiquent que $C$. chrysogaster habite une région très réduite d'environ $70.000 \mathrm{~km}^{2}$ et que l'espèce serait actuellement absent d'environ $37 \%\left(25,000 \mathrm{~km}^{2}\right)$ de sa présumée distribution historique. La classification de l'habitat de l'espèce en utilisant les images satellites indiquent que l'espèce occupait un habitat dont $58.15 \%$ était de la forêt marécageuse. La distribution et le statut de conservation de l'espèce conduisent à la conclusion que cette espèce est hautement en danger d'extinction; et les principaux menaces sur la vie de l'espèce sont le résultat de la pression humaine notamment la chasse pour la viande de brousse et le commerce pour animaux de compagnie. L'exploitation du bois constitue une menace supplémentaire parce que la quasi-totalité de sa distribution se trouverait dans les concessions forestières.

DOI: http://dx.doi.org/10.11609/JoTT.o3185.4069-75 | ZooBank: urn:Isid:zoobank.org:pub:D0A3949B-2312-46AB-8300-47ECCD1C2752

Editor: Ian Redmond, UNEP Convention on Migratory Species, Lansdown, UK

Date of publication: 26 April 2013 (online \& print)

Manuscript details: Ms \# 03185 | Received 27 April 2012 | Final received 02 April 2013 | Finally accepted 04 April 2013

Citation: Inogwabini, B.-I. \& J.A.M. Thompson (2013). The Golden-bellied Mangabey Cercocebus chrysogaster (Primates: Cercopithecidae): distribution and conservation status. Journal of Threatened Taxa 5(7): 4069-4075; http://dx.doi.org/10.11609/JoTT.03185.4069-75

Copyright: (C) Inogwabini \& Thompson 2013. Creative Commons Attribution 3.0 Unported License. JoTT allows unrestricted use of this article in any medium, reproduction and distribution by providing adequate credit to the authors and the source of publication.

Funding: The Zoological Society of Milwaukee; Wildlife Conservation Society; World Wide Fund for Nature; Lukuru Wildlife Research Project; Swedish University of Agricultural Sciences

Competing Interest: None.

Acknowledgements: Data from Salonga National Park were collected while the first author was working for the Zoological Society of Milwaukee. Data from the Lake Tumba - Lake Maindombe hinterland were collected through the World Wide Fund for Nature Lac Tumba Project, funded by the Central African Regional Program for Environment (CARPE) of the US Agency for the International Development. However, the views expressed herein are those of authors and do not necessarily reflect the views of the USAID. Data collected by the second author were submitted under the auspices of and funded by the Lukuru Wildlife Research Project. We would like to thank field teams from the Lukuru Wildlife Research Project and Lac Tumba Project. We thank Omari Ilambu, MIKE Salonga Coordinator, for sharing with us the project's raw data. Dr. Elizabeth Ann Williamson commented on the final version of the manuscript. Finally, two anonymous reviewers extensively commented on the early draft, which helped improve the quality of this final draft. The writing up of the paper was financed by the Swedish University of Agricultural Sciences, as part of Post Doctoral Research Grant to Bila-Isia Inogwabini.

Author Contribution: BILA-ISIA INOGWABINI designed the survey for the Salonga National Park and the region between Kwa-Kasai and Lulonga Rivers. He collected and analyzed the data and wrote the manuscript.

Jo A. MYERS Thompson designed the survey for the southern the Salonga National Park and the Lokoro and the Lokoro - Looto Salonga areas. She collected data share them and corrected the manuscript.
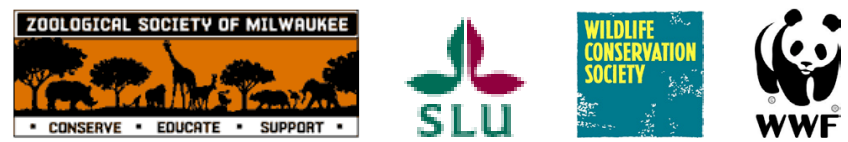


\section{INTRODUCTION}

The Golden-bellied Mangabey Cercocebus chrysogaster Lydekker, 1900 is one of Africa's least studied and most inadequately known primates (Kingdon 1997; AZA 2003). Its description by Groves (1978) was based on 15 skins, 10 of which are housed in the Tervuren Museum, Belgium. These specimens were collected from localities in the Democratic Republic of Congo (DRC), south of the Congo River. Remarkable outliers were reported to have come from: (1) Lwaza, (2) Samangwa, (3) Lubonga, (4) between Lusambo and Punia (Groves 1978). The presence of the species in these locations today is questionable. Kingdon (1997) and Gautier-Hion et al. (1999) indicated that the species occurs in swampy habitats of the DRC's 'cuvette centrale' and particularly throughout the region of the Salonga National Park (SNP). It has been presumed that the difficulties in accessing this type of habitat would provide some protection against insidious effects of intensive hunting by providing a refuge for the species, but hunters using canoes are also able to penetrate inundated forest where the water is deep enough (Steve Taylor, pers. comm. November 2012).

The 1996 Action Plan for African primates (Oates 1996) recommended surveys on the Golden-bellied Mangabey as high priority. However, till date there have been no field studies devoted solely to this species in its natural habitat. A consequence of the absence of field research dedicated to this species is that the geographic distribution of $C$. chrysogaster has been poorly known and the conservation status remains classified as "Data Deficient" (Kingdon 1997; Butynski et al. 2000; Groves et al. 2005; Hart et al. 2008). However, leading zoological facilities consider the species to be endangered (AZA 2003).

The taxonomy of this mangabey continues to be debated, with some classifications downgrading $C$. chrysogaster to the subspecies level. A subspecies taxonomic status may have negatively influenced the commitment of the conservation and scientific communities for research into the species ecology and conservation. Historically, the Golden-bellied Mangabey has been variously classified as Cercocebus chrysogaster (Kingdon 1997; Groves 2001), Cercocebus agilis chrysogaster (Dorst 1970; Groves 1978; Wilson \& Reeder 1993; Rowe 1996; Gautier-Hion et al. 1999; AZA 2003), and Cercocebus galeritus chrysogaster (Napier \& Napier 1967; Wolfheim 1983; Colyn 1988; Oates 1996; Grubb et al. 2003; IUCN 2007). Most recent arguments (Kingdon 1997; Groves 2001, Groves et al. 2005; C. Groves pers. comm. 2007), however, appeal for full species status. In order to provide an accurate status for $C$. chrysogaster, field research is required to systematically document its distribution and abundance, to evaluate threats to its survival, and to define the species ecology (Grubb et al. 2003). This paper presents preliminary field information on the $C$. chrysogaster distribution and assesses threats to the species.

\section{METHODS}

Information presented here was gathered throughout three large mammal field surveys conducted between 1994 through 2007. Surveys covered the region proposed as the species range bordered in the south by the Kasai-Sankuru River and limited in the north by the Ruki-Tshuapa-Salonga River (Fig. 1). Specific survey blocks (Fig. 1) were: (1) across the $24,000 \mathrm{~km}^{2}$ landscape defined at the southern limit by the Sankuru River and going north to include twenty percent of the SNP comprised by the watershed of the Lokoro River systems during the period intermittently between 1994-2006 (Thompson unpub. data, 1997, 2002), (2) the region between the Lokoro River to the Salonga-Looto River during the period 1997-2002 (Inogwabini \& Omari 2005; Reinartz et al. 2006) within the SNP, and (3) the region between the Kwa-Kasai and Lulonga rivers, west of lake Maindombe, including the area between the Lulonga River and Congo River, the swamps of Ngiri River, the forest between the Ngiri and Ubangi rivers, and the forest around and adjacent to Lake Tumba; limited in the north by a straight line from Mobeka parallel to the equator joining the Ubangi River during the period 2005-2007. All three surveys combined three methods: (1) straight line transects with variable lengths (Buckland et al. 1993; Hall et al. 1997), (2) comprehensive or guided reconnaissance (Walsh et al. 2001; Blake 2002), and (3) forest exploration, known as reconnaissance (Hall et al. 1997; Van Krunkelsven et al. 2000; White \& Edwards 2002). The two latter methods differ only in the fact that during a comprehensive reconnaissance observers follow a compass direction with restriction to deviate by $45^{\circ}$ from the main orientation (White \& Edwards 2000; White et al. 2001). During surveys, direct sighting and/ or indirect signs were recorded on large mammals such as great apes, diurnal primates, elephants, and duikers. Indirect signs for diurnal primates consisted of calls only. Field survey data were complemented by information gathered from focus group discussions held in 2006 along the road between Anga and Mundja (Thompson 


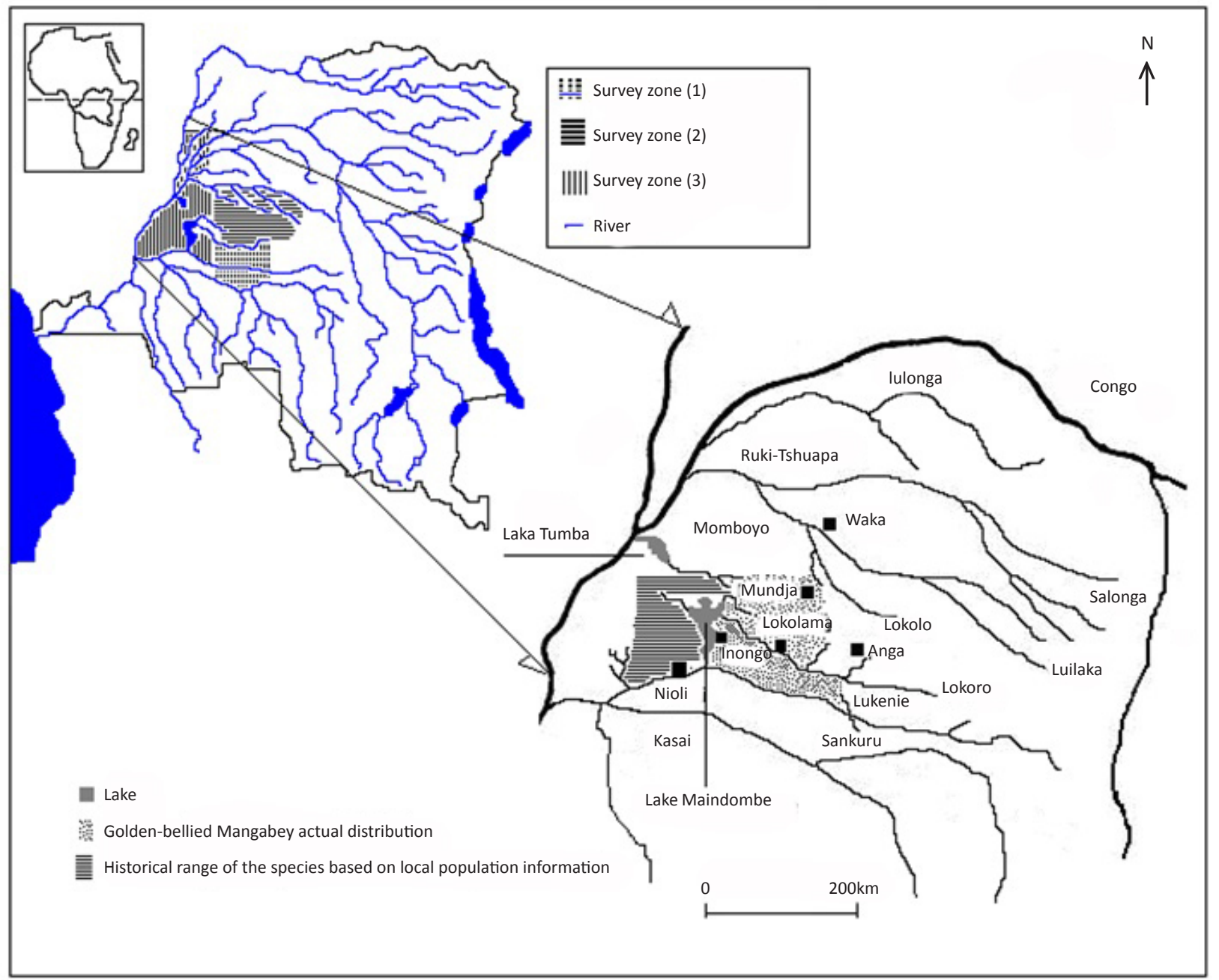

Figure 1. Survey zones and plotted distribution of Cercocebus chrysogaster

unpub. data). During focus group discussions pictures of live Golden-bellied Mangabey were presented to local trackers for identification. In other areas within the survey zone, the investigation consisted of nonstructured interviews/conversations with local trackers and aged people along roads and rivers at villages that teams visited before accessing the forests. Furthermore, information gathered from conventional survey methods, focus group discussions and non-structured interviews was complemented by communications provided by other field researchers working in the region (e.g., Jonas Eriksson, Jeff Dupain, and Omari llambu). The species was confirmed in the region of Lui Kotale $\left(1^{\circ} 00^{\prime}-3^{\circ} 20^{\prime} S\right.$ \& $20^{\circ}-22^{\circ} 30^{\prime} \mathrm{E}$ ) during surveys by the Monitoring of Illegal Killing of Elephant / MIKE program (Omari llambu pers. comm. 2007). Direct evidence of the Golden-bellied Mangabey (sighting and/or calls) was recorded and georeferenced with hand-held Garmin GPS units (Waters \&
Shockley 2000). However, the distribution information came primarily from direct field observations.

Because C. chrysogaster was previously described as a species that preferred swampy habitat, a post hoc habitat classification was done using dual habitat matrices, (1) water habitat or (2) terra firma, to provide inference on the habitat choice. Analysis was done using the LandSat Images of the region provided by the Observatoire Satellital des Forêts d'Afrique Central (OSFAC) and the University of Maryland. Locations were plotted using the geographical information system ArcView v. 3.2 (ESRI, Redlands, USA). The same software was also used to differentiate forest types.

The information on the conservation status of the species was collected through three different methods. First, in 2001 data were collected along the road from Mundja down to Lompole. Data consisted of a simple count of readily identifiable freshly-killed mammal 
species carried by people passing along the road. The data were collected in 48 hours at Mundja and Ipope, respectively. In 2007, complementary data were collected from single sweep market surveys carried out at

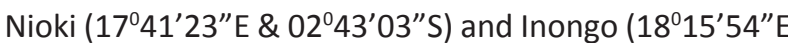
\& $01^{0} 56^{\prime} 59^{\prime \prime}$ ) $)$, which took approximately three hours at each market. Results presented in this paper are simple percentages of the presence of $C$. chrysogaster in the sample. These were judged to be a good indicator for the real conditions of the species throughout its range.

\section{RESULTS}

Evidence from the field suggests that the distribution the $C$. chrysogaster is limited to altitudes ranging within 300-500 m. Thompson (1997) confirmed the presence of the Golden-bellied Mangabey west of the SNP southern sector boundary, but the species was not recorded or known in the SNP in the wide tract between Anga and Mundja. However, the MIKE data clearly indicated that the species was present in the southernmost tip of the SNP in the region of Luikotal; $20 \mathrm{~km}$ from the Mundja Lokolama road, an area where swampy forest is extensive and forest-savannah mosaic constitute one of the major patterns of the terra firma habitat. Field data collected by Inogwabini during several field missions between 1997 and 2002 (B.-I. Inogwabini pers. obs. January 1997; August 2001; November 2001; March-April 2002; May-June 2003) confirmed by direct observation the presence of the Golden-bellied Mangabey in the region south of the Momboyo-Lokolo River system, particularly in the region of Mundja $\left(20^{\circ} 26^{\prime} \mathrm{E} \& 02^{\circ} 32^{\prime}\right.$ S; Fig. 1) and along the road to Lompole $\left(20^{\circ} 00^{\prime} 43^{\prime \prime} \mathrm{E} \& 02^{\circ} 01^{\prime} 03^{\prime \prime} \mathrm{S}\right)$ and Lokolama $\left(19^{\circ} 01^{\prime} 58^{\prime \prime} E \& 02^{\circ} 00^{\prime} 26^{\prime \prime} S\right)$. The species was absent in the northernmost edge of the forest block between Luilaka-Momboyo and Lokolo rivers, which was also the case for the entire northern sector of the SNP and the forest block between the two sectors. South of the Kasai-Lukuru system, the species was absent from a mosaic of forest-savannas in the region of Lukuru in Kasai Occidental (Thompson 1997). Although the data collected between 2005 and 2006 suggested the absence of the species in the zone west of lake Maindombe, local populations recognized the presence of the $C$. chrysogaster (Inogwabini 2005). The species was, however confirmed in the eastern shores of lake Maindombe.

These cumulative findings indicate that the Goldenbellied Mangabey occurs in the polygon (Fig. 1) defined by the Lokolo River system $\left(\sim 2^{0} 30^{\prime} \mathrm{S}\right)$, which constitutes the known northernmost limit of its distribution, and the Kwa-Kasai-Sankuru River $\left(\sim 3-4{ }^{\circ} \mathrm{S}\right)$, which constitute the southernmost limit. On the eastern side, the limit is situated along the Ngendo River $\left(\sim 21^{0} 13^{\prime} \mathrm{E}\right)$, and western limit at the Congo River, south of Lake Tumba $\left(18^{\circ} 06^{\prime} 30^{\prime \prime} \mathrm{E} \& 00^{\circ} 53^{\prime} 14^{\prime \prime} \mathrm{S}\right)$. The surface area within this polygon is estimated at approximately $70,000 \mathrm{~km}^{2}$. This area also includes the area west of lake Maindombe, which represents approximately $38 \%$ of the estimated range $\left(25,000 \mathrm{~km}^{2}\right)$, and where the available record is solely provided by local communities. The post hoc classification of the habitat of the species within this region indicated that $58.15 \%$ was permanent swamps and or seasonally inundated forest types.

The data from simple counts on the road indicated that the C. chrysogaster constituted $>70 \%$ of hunted species encountered on the road, and was in equally high proportions in the bushmeat encountered in the market

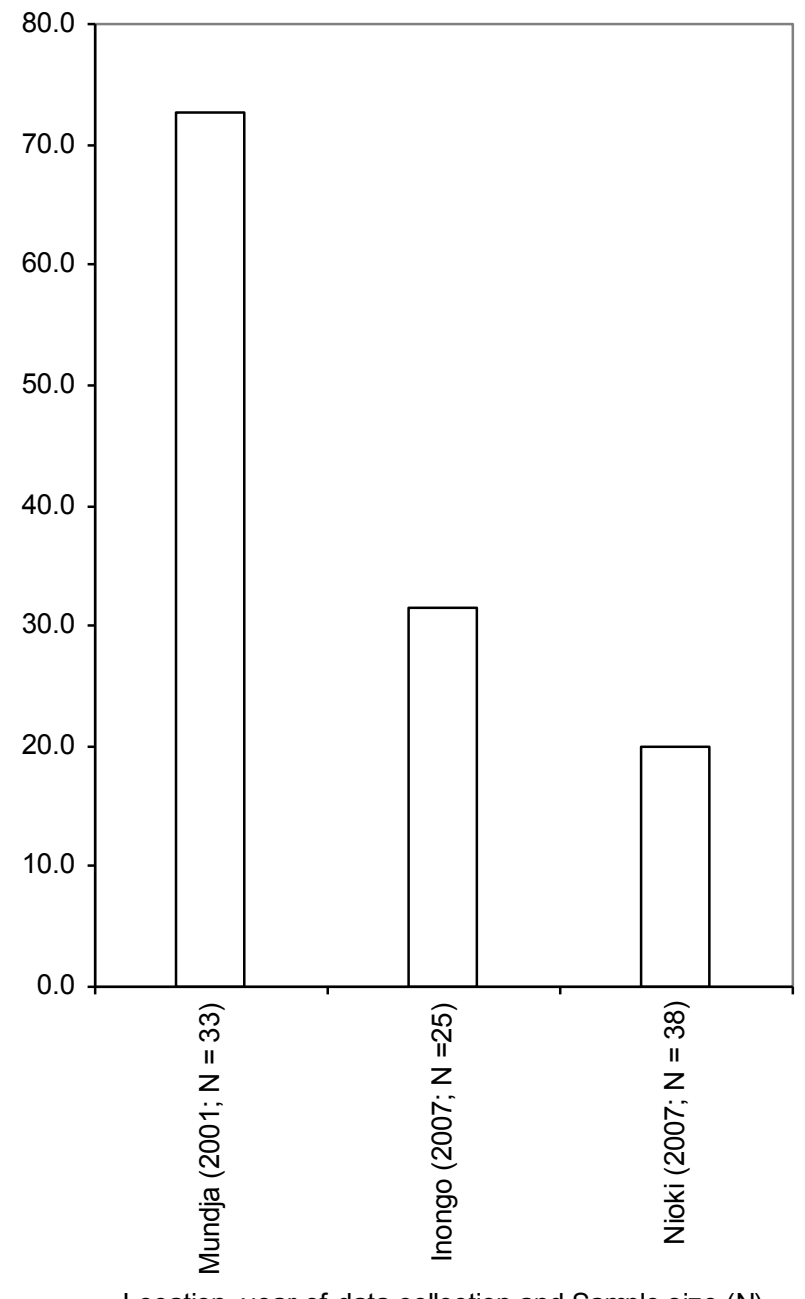

Location, year of data collection and Sample size $(\mathrm{N})$

Figure 2. Percentage of $C$. chrysogaster specimens recorded in bushmeat markets from three different localities 
of both Inongo and Nioki, with respectively $>31 \%$ and $20 \%$ of the total species encountered on the market's tables (Fig. 2).

\section{DISCUSSION}

C. chrysogaster is endemic to the Democratic Republic of Congo (Groves 1978; Bergmans 1998; SZS 2003; IUCN 2006) but does not occur north of the Congo River. Even within its range, the species is common only in the region inhabited by the Nkundo people, where it is locally known as "Linku" in the Lonkundo language (Lootens 1980; Thompson 1997). A post hoc habitat analysis indicated that $58 \%$ of the species habitat is an extensive swamp, riparian and seasonally flooded forests. This finding concurs with the description provided by Gautier-Hion et al. (1999). Dorst \& Dandelot (1969) identified the historic distribution for two discontinuous populations, the southern limit being $4^{\circ} 00^{\prime} \mathrm{S}$ as defined by the KasaiSankuru River. However, the 1997 survey by Thompson (1997) confirmed their absence along the Sankuru River east of $20^{\circ} 30^{\prime} \mathrm{E}$. At this geographical location, the altitude increases toward ridges of the eastern Congo Basin; increasing altitude diminishes proportions of the species preferred swampy habitats.

C. chrysogaster is listed as present in the Salonga National Park (IZCN 1986). Also Blom \& Tshobo (1989) included $C$. chrysogaster in their list of the mammals of the SNP, but indicate that its distribution in the SNPPNS is limited to the southern sector. Similarly, Gautier-Hion et al. (1999) described the species as occurring mainly south of the Luilaka River (Fig. 1), with a minor portion of the habitat being above the Ruki-Tshuapa River. Our finding that the Lokolo River system constitutes the known northernmost limit of the distribution of the Goldenbellied Mangabey indicates clearly that the distribution presented by Gautier-Hion et al. (1999) over-estimated the actual range of the species. Also, the fact that local populations between the Lake Maindombe and Congo River recalled the presence of $C$. chrysogaster from the past may suggest that the Congo River constitutes the most likely westernmost historical limit of the distribution. This maximum range is nevertheless, to be viewed with caution as there are large areas within that are probably void of $C$. chrysogaster. This is particularly the case in the forest stretch lying south of Lukenie where Eriksson (2002) did not find any indication of the species over a trip of several months in the field. However, it seems more plausible that records from Gautier-Hion et al. (1999), the remarkable outlier specimens described by
Groves (1978) and the local information gathered in the lake Maindombe-Congo River forest blocks may simply mirror either the plight that the species decline that has been known for a long time or simply misclassifications.

From both results and discussion presented above, it can be concluded that the Golden-bellied Mangabey has a more restricted distribution range than many other sympatric primate species such as the Black Mangabey Lophocebus aterrimus or the Angolan Pied Colobus Colobus angolensis. This limited range adversely impacts the potential survival of this species, particularly if no protection efforts are made. By its restricted range alone, $C$. chrysogaster deserves more attention than it is currently receiving. Its categorization by the International Union for Conservation of Nature (IUCN) remains unrated due to deficient data (Lee et al. 1988; Hart et al. 2008), which has potentially contributed to an assigned lower conservation priority compared to other endemic species in species conservation priorities assessment such as the exercise carried out by Oates (1996). C. chrysogaster is not even identified in the list of species and their protected status in the national law in the Democratic Republic of Congo (Kisoka 2000) or by any international conventions for protection (except that all non-human primates not listed on Appendix I of CITES are included in Appendix II so any international trade would require CITES permits). However, data on bushmeat from different localities within the species range and its directly adjacent regions indicated that the species was hunted for its meat and may constitute the most hunted primate species in regions such as Mundja where it counted for $>70 \%$ of the overall hunted species in a 48 hours time span (Colom et al. 2006).

Wolfheim (1983) identified habitat alteration (including forest clearance) and human consumption as the most important threats to wild populations of primates. Data recorded during the simple counts along roads and the one-off market sweep surveys (Fig. 2) indicated that $C$. chrysogaster is heavily hunted for meat. Along the road between Mundja and Lokolama, groups of individuals of $C$. chrysogaster gather frequently in the proximity of roads and villages. The species has been identified by villagers as an agricultural pest (J.A.M. Thompson pers. obs. 2006), which may lead to persecution of the species. Also because the species can be found in groups of $\leq 15$ individuals foraging on the ground (Gautier-Hion et al. 1999) around villages, they are a relatively easy target for hunters.

Results from personal observations suggested that the species is targeted for the pet trade. Specifically, in 2002 an expatriate invited some colleagues and Inogwabini to 
identify two monkeys she had bought on the streets in Kinshasa. She was trying to identify the species in order to determine what zoos might be interested in acquiring them. The team identified the two primates as Goldenbellied Mangabeys. In early 2003, a total of 21 live Golden-bellied Mangabeys were located at three places in Kinshasa: 10 in the art market (Boulevard of 30 Juin), nine at the street flower market near Kintambo-Magasin, and two within the compound of the ESSET (Boulevard of 30 Juin), a society dealing with solar energy. Later that same year, merchants were encountered in the region of Waka (Fig. 1) with four Golden-bellied Mangabeys that they said were captured near the Lokolo River (Fig. 1). The merchants were waiting for a boat to transport their cargo down to Kinshasa where the live individuals would be sold.

Habitat alteration is another threat to the survival of the $C$. chrysogaster because the region encompassed by the heart of the species range has been allocated to logging concessions (Reinartz \& Inogwabini 2001) and the area west of the Lake Maindombe (Fig. 1) where local communities indicated the presence of the species in the distant past (more than three decades ago) but the forest has been logged and re-logged several times in the recent past (the last two decades). The recent and remote histories of logging in this region may have played a key role in the actual patterns of the species distribution within its historical range.

In conclusion, combining the restricted range of the species, the hunting levels and logging activities in the region of the heart of the distribution of species, $C$. chrysogaster should be viewed as one of the threatened endemic species in the Democratic Republic of Congo, at least at the national level. Indications of the species being hunted for pets and zoos also supports the request that C. chrysogaster should be listed on CITES. Finally, for the long-term conservation strategy for the species, focused research is required to better understand the species' distribution, taxonomy and behavioural ecology, and to evaluate thoroughly its conservation status throughout its actual distribution and historical range.

\section{REFERENCES}

AZA (American Zoos Association) (2003). Golden-bellied Mangabey: Species Survival Plan. Prepared by L. Field, Species Coordinator, Sacramento Zoological Society.

Bergmans, W. (1998). Biological diversity of the Congo basin, pp. 1724. In: Besselink, C. \& P. Sips (eds). The Congo Basin - Human and Natural Resources. UICN Netherlands.

Blom, A. \& M. Tshobo (1989). Reconnaissance des Eléphants de Foret au Zaïre: Deuxième partie. Rapport de Mission WCI/IZCN/WWF.
Buckland, S.T., D.R. Anderson, K.P. Burnham \& J.L. Laake (1993). Distance Sampling - Estimating Abundance of Biological Populations. Chapman \& Hall, London.

Butynski, T. \& Members of the Primate Specialist Group (2000). Cercocebus galeritus ssp. chrysogaster. In: IUCN 2006 Red List of Threatened Species. <www.iucnredlist.org>. Downloaded on 10 January 2007.

Colom, A., B.K. Ludia, I. Edumbadumba, A. Nsuku, A.M. Kapundu, Y. Muzima, B. Ntumbanzondo \& E. Steel (2006). Aspects socioéconomiques de l'utilisation et de la gestion des ressources naturelles dans le paysage Salonga-Lukenie-Sankuru: Un guide pour la conservation et I'amélioration des conditions de vie. Available on the website: http://carpe.umd.edu/resources/Documents/SLS_ Landscape_Rpt_SE_WWF2006_FR.pdf/view

Colyn, M. (1988). Guenons' distribution in the Zaire Basin. In: GautierHion, A., F. Bourliere, J.P. Gautier \& J. Kingdon (eds). A Primate Radiation: Evolutionary Biology of The African Guenons. Cambridge University Press.

Dorst, J. (1970). A Field Guide to the Larger Mammals of Africa. Houghton Mifflin Company, Boston.

Dorst, J. \& P. Dandelot (1969). A Field Guide to The Larger Mammals of Africa. Houghton Mifflin Company, Boston.

Eriksson, J. (2002). Animal and human activity in the area of the southern block of the Salonga National Park, Democratic Republic of Congo. Report submitted to the MIKE Program - Wildlife Conservation Society.

Gautier-Hion, A., M. Colyn \& J.P. Gautier (1999). Histoire naturelle des primates d'Afrique Centrale. ECOFAC - UDEAC Multipress, Libreville.

Groves, C.P. (1978). Phylogenetic and population systematics of the mangabeys (Primates: Cercopithecoidea). Primates 19: 1-34; http:dx.doi.org/10.1007/BF02373224

Groves, C.P. (2000). The phylogeny of the Cercopithecoidea. In: Whitehead, P.F. \& C.J. Jolly (eds), Old World Monkeys. Cambridge University Press.

Groves, C.P. (2001). Primate Taxonomy. Smithsonian Institution Press, Washington, DC.

Groves, C.P., D. E. Wilson \&, D. M. Reeder (eds). (2005). Mammal Species of the World - $3^{\text {rd }}$ Edition. Johns Hopkins University Press.

Grubb, P., T.M. Butynski, J.F. Oates, S.K. Bearder, T.R. Disotell, C.P. Groves \& T.T. Struhsaker (2003). Assessment of the Diversity of African Primates. International Journal of Primatology 24(6): 13011357; http://dx.doi.org/ 10.1023/B:IJOP.0000005994.86792.b9

Hall, J.S., B.I. Inogwabini, E.A. Williamson, I. Omari, C. Sikubwabo \& L.J.T. White (1997). A survey of Elephants (Loxodonta africana) in the Kahuzi-Biega National Park lowland sector and adjacent forest in eastern Zaire. African Journal of Ecology 35: 213-223; http://dx.doi. org/ 10.1111/j.1365-2028.1997.088-89088.x

Hart, J., T.M. Butynski \& Y.D. Jong (2008). Cercocebus chrysogaster. In: IUCN 2012. IUCN Red List of Threatened Species. Version 2012.2. <www.iucnredlist.org>. Downloaded on 20 April 2013.

IZCN (Institut Zaïrois pour la Conservation de la Nature) (1986). Premier Séminaire International sur la gestion et l'avenir du Parc National de la Salonga. Mbandaka, 18-21pp.

Kingdon, J. (1997). The Kingdon Field Guide to African Mammals. Academic Press.

Kisoka, M. (2000). Recueil des textes juridiques en matière environnementale en R.D. Congo. Imprimeries Saint Paul, Kinshasa.

Lee, P.C., J. Thornback \& E.L. Bennet (1988). Threatened Primates of Africa. IUCN, Gland.

Lootens, P. (1980). Vocabulaire comparé de noms d'animaux: Lokundo - Lotoa - Lolube - Lokonda. Annales Aequatoria 1: 449-465.

Napier, J.R. \& P.H. Napier (1967). A Handbook of the Living Primates: Morphology, Ecology, and Behaviour of Nonhuman Primates. Academic Press, London.

Oates, J.F. (1996). African Primates: Status Survey and Conservation action plan. Revised Edition. IUCN, Gland.

Reinartz, G.E. \& B.I. Inogwabini (2001). Bonobo survival and the wartime mandate. In The Great Apes: Challenges for the $21^{\text {st }}$ Century. Conference proceedings, Brookfield Zoo, 52-56pp. 
Reinartz, G., B.I. Inogwabini, N. Mafuta \& W.W. Lisalama (2006). Effects of forest type and human presence on bonobo (Pan paniscus) density in the Salonga National Park. International Journal of Primatology 27(2): 603-634; http://dx.doi.org/10.1007/s10764-006-9020-9

Rowe, N. (1996). The Pictorial Guide to the Living Primates. Pogonias Press, New York.

The Sacramento Zoological Society (2003). Golden-bellied Mangabey - Cercocebus galeritus chrysogaster. http://www.saczoo.com/1_about/_animals/fact_sheets/ (Accessed on 10 January 2007)

Thompson, J.A.M. (1997). The history, taxonomy and ecology of the Bonobo (Pan paniscus Schwarz 1929) - with a first description of a wild population living in a forest-savanna mosaic habitat. PhD Thesis, Oxford, UK.

Thompson, J.A.M. (2002). Bonobos of the Lukuru Wildlife Research Project, pp. 61-70. In: Boesch, C., G. Hohmann, \& L.F. Marchant (eds). Behavioural Diversity in Chimpanzees and Bonobos. Cambridge University Press.

Walsh, P.D., L.J.T. White, C. Mbina, D. Idiata, Y. Mihindou, F. Maisels \& M. Thibault (2001). Estimates of forest elephant abundance: projecting the relationship between precision and effort. Journal of Applied Ecology 38(1): 217-228; http://dx.doi.org/ 10.1046/j.13652664.2001.00578.x

Waters, K. \& I. Shockley (2000). Using ArcView 3.1 with a WIPS. www.nws.noaa.gov

Wilson, D.E. \& D.M. Reeder (eds.) (1993). Mammal Species of the World: A Taxonomic and Geographic Reference - Second Edition. Smithsonian Institution Press, Washington. DC.

Wolfheim, J.H. (1983). Primates of the World: Distribution, abundance, and conservation. The New York Zoological Society and University of Washington Press.
Author Details: BILA-ISIA INOGWABINI has a PhD in Wildlife Management from the University of Kent at Canterbury UK. He has been working applied conservation research for 20 years across Central Africa. Currently associated with the Swedish University of Agricultural Sciences, Uppsala. His current diversified scientific interests include applied primate conservation research.

Jo A. MYeRs Thompson has a PhD in Primatology from Oxford University. Dr. Thompson founded and runs the Lukuru Wildlife Research Center, from where ecological data on bonobos and other primates have been collected over two decades. She promotes the empowerment of local scientists to conserve the biodiversity of the Democratic Republic of Congo. 